\title{
Effects of Web-Based Learning and Cultural Literacy Towards Non-formal Educator Performance
}

\author{
Rusdin Djibu*, Ummyssalam Duludu \\ Universitas Negeri Gorontalo, Indonesia \\ *Email: rusdindjibu@ung.ac.id \\ Submitted: 31 December 2020. Revised: 31 January 2021. Accepted: 13 February 2021
}

\begin{abstract}
The purpose of this research is to find out: (1) the influence of Web-based learning with the performance of Educators, (2) the influence of cultural literacy with Educators' performance (3) the influence of Web-based learning and literary culture together with performance Educators. The method used in this study was with a quantitative approach with the ex-post-facto method. The population in this study was all non-formal educators working in the Gorontalo City learning activities workshop amounting to 107 people, while samples were 59 people using proportional random sampling. Data is collected through poll deployments. The conclusion to this research is (1) there is a positive influence on Web-based learning on educators' performance, which means that the better web-based learning is better for educator performance. (2) there is a positive influence on the cultural literacy of the educator's performance, meaning that both the literate culture is also the higher the performance of educators. (3) there is a positive influence on web-based learning and cultural literacy together to the performance of educators working in the Learning Activities workshop in Gorontalo city, this means that the higher the implementation of Web-based learning and culture of literacy, the higher the performance of non-formal educators.
\end{abstract}

Key words: web-based learning, literacy culture, civil service performance

How to Cite: Djibu, R., \& Duludu, U. (2021). Effects of Web-Based Learning and Cultural Literacy Towards Non-formal Educator Performance. Journal of Nonformal Education, 7(1), 71-82.

DOI: http://dx.doi.org/10.15294/jne.v7i1.28171

\section{INTRODUCTION}

Educator performance is an important element in education, but also a high determinant of the low quality of education. Educator performance performed by educators in carrying out the duties of an educator as an educator (Celik, 2011). The quality of educators ' performance is crucial to the quality of education outcomes as educators are the ones who interact most directly with learners during the learning process. Educators are an important component in the world of education (Patrick, 2011), Therefore more attention needs to be given to creating quality educators so that it can support the performance of educators. Educators also play an important role in the world of education, especially in the formal field of school, educators determine the success of students especially in the teaching and learning process that is commonly implemented in schools.

Educator performance is the result of work that can be achieved by an educator at an educational institution or madrasah following the duties and responsibilities of achieving educational objectives (Asf, J., \& Mustofa, 2013). An educator is required to be creative and innovative in developing integrating rules using technology in learning activities. Teacher effectiveness refers to a set of within-person attributes - personality, motivation, beliefs, and dispositions - that interact with contextual factors (cultural, social, educational) to influence student outcomes (Klassen \& Kim, 2019). The success of an educator must meet the criteria set, when educators have fulfilled these criteria meaning an educator can be said to be successful and have good quality. Conversely, if an educator has not fulfilled good criteria, then the educator can not be successful.

The role of technology supports the teaching and learning process in this digital age because it can help students to become independent learners (Rafiola, Setyosari, Radjah, \& Ramli, 2020). The development of science and technology today increasingly encourages the renewal of technology utilization in the learning process as one to improve the quality of education. Two lines of research flourished in the last decades in educational research: self-regulation and computer-based learning (Müller \& Seufert, 2018). The role of educators is not just as a knowledge or information learner but more on how learners can learn the most to make use of interesting media including providing a variety of learning resources that learners can learn. Educational innovation is a primary need especially based on ICT or information and communication technology (Voogt, Knezek, Cox, Knezek, \& Ten Brummelhuis, 2013). So, it is expected to improve the quality of education that affects better learning outcomes. One of the innovations in technology utilization in the learning process is through web-based learning.

The digital century requires a constant modernization of the state service as well as in education (Israfilov et al., 2020). Information and communication technology such as computers, laptops, netbooks, and 
Handphone are now familiar to learners, as well as the Internet. The "information society" in practice means a huge rise in informational activities due to the internet and other ICT (information and communication technology) related activities (Genlott \& Grönlund, 2013). However ICT is a structural feature of Open Teaching, at the same time entails a significant risk concerning its integrality as an open educational practice, by overweighting technological aspects over educational one (Chiappe \& Lee, 2017). Various Internet access with a computer device and a Web-based learning Handphone can be implemented properly. Through this web-based learning, educators can post materials, deliver assignments, conduct quizzes, provide enrichment, discuss with learners, provide a variety of information and so on. Learning can be carried out from anywhere at any time, making it easier and more enjoyable.

The internet is said to have revolutionized human life. This is because the internet has become a means of communication and brought a new paradigm in human interaction (Saputra \& Siddiq, 2020). Along with the development of technology rapidly, the way of teaching and learning are changing accordingly

. The existence of technology is expected to make learning more active, creative, innovative and enjoyable, so that the creation of multi interactions, both among educators with students, students with educators, learners with media and Learning resources, as well as learners with other learners. Educators must be able to familiarize learners with pro-active, creative and innovative learning activities. The development of information and communication technology capable of processing, packing, and displaying, and disseminating learning information in an audio, visual, audiovisual, and even multimedia, this adult has been able to realize the so-called Virtual Learning (Deni Darmawan, 2012). This concept develops so that it can package the settings and the reality of previous learning becomes more attractive and provides psychologically adaptive conditioning to learners wherever they are. Indeed, the effort in this direction is a lot of examples with the emergence of e-learning concepts that can be concluded that learning is not difficult although limited by space and distance is not possible if done in nature.

In Indonesia, this may be done through a Continuing Professional Development (CPD) program aims to improve the knowledge, skills and professional attitudes of principals (Sukarno \& Sumarwati, 2020). Based on the results of preliminary studies on informal education Gorontalo City can be seen from the performance indicators of educators who have not demonstrated optimal performance and still far from the ideal score that is: (1) Less working quantity due to still Many educators who are absent every month
(2) Low quality work because of educators who do not pay much attention to the thoroughness and fragility in carrying out their work (3) Low cooperation because there are still educators The difficulties of having to cooperate with certain educators (4) responsibilities still have a low percentage, this is because educators who don't want to acknowledge their work and mistakes in less precise decision making (5) Initiatives that are still low, this is evident from the situation in which educators do not have a personal initiative to do other jobs at the time of their leisure, but some educators only fill their time with other things outside of work.

Based on the results of observations in the nonformal education of Gorontalo city that most of the learners are proficient to use the phone, but the phone is only used to play games or watch YouTube. There has been no educator initiative to provide learning tasks or materials over the Internet by using learning application facilities. Besides, most educators do not yet know even understand how the learning app works. Besides, factors that contribute to the performance of educators in the implementation of learning is a culture of literacy. One's literacy is evident in the reading, writing, counting and speaking activities. Every scholar or educator is sure to read, but not all scholars or educators can write. The quality of the writing depends on the reading content it reads. The content appears when speaking. The importance of coaching literacy school educators as a step-in improving literacy or literacy coaching educators to support the school Literacy Movement (GLS). Regulation of the Minister of Education and Culture of the Republic of Indonesia number 23-year 2015 about the growth of ethics.

Unconsciousness that low interest in reading is a problem. The lack of consciousness to read, many people as if suffice science with electronic devices and internet networks. Books are considered impractical and time-consuming than online information that credibility is still doubtful. One of the best things about it as educators to help learners achieve success in this culture is to help students to the fullest extent of literacy and literate. Involving all intelligence will be easier, to understand the different ways in which literacy itself is studied and practiced (Thomas, 2013). A description of the performance of three important components is purpose, size, and judgment. Goal setting of each organizational unit is a strategy to improve the organization.

However, the goal is not enough, therefore it takes the size of whether an officer has achieved the expected performance. According to (Koswara \& Rasto, 2016) performance may be interpreted as follows: Performance is the measurement of a result, it ask the simple question: did you get the job done, to reward 
people and the organization, therefore, requires some agreed-upon criterion for defining the performance. The meaning is performance is a measure of the work done using the criteria that are jointly agreed upon. Besides, there is an opinion that says that at times the performance is only a form of response, but usually the result of the product. While Patricia King argues that performance is a person's activity in carrying out basic tasks that have been charged to him. Good performance (Vipraprastha \& Sari, 2016), skills, abilities and individual traits.

Referring to that view, it can be taken to understand that a person's performance is always connected with routine tasks undertaken. Meanwhile, (Yani, 2016) Suggests that performance is the result of interaction or proper functioning of elements of motivation, ability, and achievement that is found in one's self. Next (Zhu, Chew, \& Spangler, 2005) performance is the application of competencies to achieve success through the implementation of a task. Did (Zhu et al., 2005) there are outside environmental factors and working climate organizations that contribute to the performance of educators. Environmental factors play a role in affecting the patterns of change that occur in the organization, such as in a state of enormous economic pressure such as high inflation, recession or depression will affect the organization that is forced to take New wisdom in the wage, provision of benefits, promotion and so on. The performance assessment of workers is based on competencies associated with important targets of the organization.

The performance of educators is not solely aimed at getting as many works, but the quality of work is also important to note, as it is disclosed that performance appraisal is crucial to the effectivity management of an organization's human resources, and the proper management of human resources is a critical variable affecting an organization's productivity (Susilo, 2017). Individual performance can be assessed by what the individual does in his work, i.e. how he or she does the job or the demonstration. Human resources are the efforts, skills, and capabilities that people contribute to an employing organization that enables it to continue in existence (Zhu et al., 2005). In this case, productivity can be reviewed based on its level with each benchmark, which can be seen from the educator's performance. Performance or performance can be interpreted as work achievement, job execution, achievement, work or work performance. In line with that, performance is output drive from processes, human or otherwise. So performance is the result or output of a process (Kusuma, 2017).

The purpose of this research is to determine the level of educators ' performance in nonformal educa- tional institutions. While the focus of this research is to discuss the impact of website-based learning and cultural literacy on the special performance of Nonformal educators. This research can be beneficial to answer any factors that affect the performance of nonformal educators. The results of this research can be used as a reference for educators, especially for informal education in the city of Gorontalo, Indonesia.

\section{METHODS}

This research uses a quantitative approach with the ex-post-facto method. This analysis is to test the magnitude of the influence of variables independent of the dependent variable. This research consists of independent variables and dependent variables. The free variables are web-based learning (X1) and the Literate culture (X2). While the variable is tied is performance educator $(\mathrm{Y})$. The population in this research is the overall characteristic associated with web-based learning, cultural literacy and the performance of educators. The population in this study is the entire educator of the city of Gorontalo with a total of 107 people. The samples in this study were as much as 55\% of the population, so the number of samples in the study amounted to $55 \%$ X $107=58.5$ or was completed to generate 59. Subsequently, the samples were pulled using proportional random sampling. The Data in this study was analyzed descriptively and inferential. The descriptive analysis includes, mean, standard error of the mean, median, standard deviation, Variance, skewness, kurtosis, range, quartile, and percentile. The inferential analysis includes regression analyses in simple regression and multiple regression. Calculation of both descriptive analysis and inferential analysis using SPSS program version 21.0.

\section{RESULTS AND DISCUSSION}

The results of a descriptive analysis of research data on three research variables, (a) educator performance (Y), (b) Web-based Learning (X1), and (c) Cultural Literacy (X2). The descriptive analysis used includes; Mean, standard error of the mean, median, standard deviation, skewness and standard error of skewness, kurtosis and standard error kurtosis, range, minimum and maximum values, and percentiles.

Based on the results of the descriptive analysis output with SPSS program version 21.0 for educator performance data obtained the following results:

1) $\mathrm{N}$ or the amount of valid data (valid for processing) is 62

2) The mean or average performance score of educators is 105.42 with default error 1.12. At a trust 
rate of $95 \%$ with the default error of mean 1.12 Then it is estimated that a large average educator performance score estimated from the sample is $105.42 \pm(2 \times 1.12)=$ score 103.18 up to a score of 107.66

3) The Median or midpoint data if all data is sorted and divided by two equally large. The median number 106.00 showed that the $50 \%$ educator performance score was 106.00 upwards and 50\% was 106.00 down.

4) The standard deviation is 8.81 . For that at a confidence level of $95 \%$ with a standard deviation of 8.81 then, the average dispersion of the sample is $105.42 \pm(2 \times 8.81)=$ A score of 87.80 up to a score of 123.04

5) The Skewness size is-0.32. For the assessment, the value is changed to the ratio number. The skewness ratio is the skewness value/default error skewness. Thus, the ratio skewness =$0,132 / 0,304=-4.34$. As a guideline, if the skewness ratio is between- 2 to +2 , then the distribution of data is normal. Therefore- 0.434 lies in the area between- 2 and +2 Hence it can be concluded that the educator's performance data is normal.

6) Data minimum is score 80.00 and maximum data is score 123

7) Range is maximum data - minimum data is score 43

8) Percentiles or percentile numbers:

- Average educator performance score $10 \%$ of respondents are under 94.30

- Average educator performance score $25 \%$ of respondents are under 100.75

- Average educator performance score $50 \%$ respondents are under 106.00

- Average educator performance score $75 \%$ respondents are under 111.25

- Average educator performance Score 90\% respondents are under 116.70

9) Frequency distribution of cultural literacy scores

Table 1. Educator Performance score frequency distribution

\begin{tabular}{lcc}
\hline $\begin{array}{l}\text { Interval } \\
\text { classes }\end{array}$ & $\begin{array}{c}\text { Frequency } \\
\text { Absolut }\end{array}$ & $\begin{array}{c}\text { Frekuensi } \\
\text { Relatif }(\%)\end{array}$ \\
\hline $80-86$ & 1 & 1.61 \\
$87-93$ & 4 & 6.45 \\
$94-100$ & 10 & 16.13 \\
$101-107$ & 23 & 37.10 \\
$108-114$ & 16 & 25.81 \\
$115-121$ & 6 & 9.68 \\
$122-128$ & 2 & 3.23 \\
Total & 62 & 100 \\
\hline
\end{tabular}

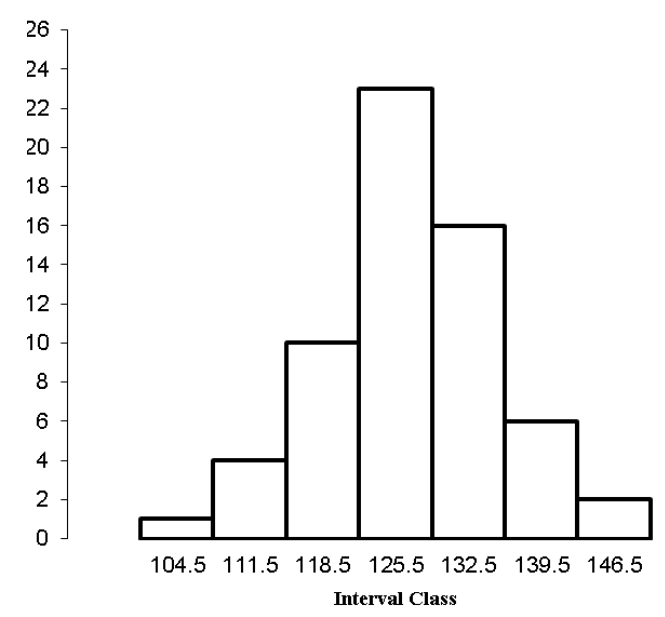

Figure 1. Histogram Frequency of educator performance

Figure 1 indicates that the data grouping is based on calculations by using Sturges rule obtained the data centralizing values as follows; mode $=112.5$ median $=106.00$ and mean $=105.42$.

\section{Web-based Learning}

Based on the results of the descriptive analysis output with SPSS program version 21.0 for Webbased learning data obtained the following results:

1) $\mathrm{N}$ or the amount of valid data (valid for processing) is 62

2) The mean or average web-based learning score is 96.03 with default error 1.54 . At a $95 \%$ confidence level with the error of mean 1.54, it is estimated that the average web-based learning score of the population estimated from the sample is $96.03 \pm(2 \times 1.54)=$ A score of 92.94 up to a score of 99.10

3) The Median or midpoint data if all data is sorted and divided by two equally large. The median number 96.00 showed that $50 \%$ of web-based learning scores were 96.00 upwards and $50 \%$ was 96.00 down.

4) The standard deviation is 12.16. For that at a confidence level of $95 \%$ with a standard deviation of 12.16 then, the average dispersion of the sample is $96.03 \pm(2 \times 12.16)=\mathrm{A}$ score of 17.70 up to a score of 120.34

5) The Skewness size is-0.231. For the assessment, the value is changed to the ratio number. The skewness ratio is the skewness value/default error skewness. Thus, the ratio skewness =$0,231 / / 0,304=-0.76$. As a guideline, if the skewness ratio is between- 2 to +2 , then the distribution of data is normal. Therefore- 0.76 is located on the area between-2 and +2 It can be concluded that the Web-based learning data is normal attribution. 
6) Data minimum is score 65.00 and maximum data is score 120

7) The range is maximum data - minimum data is score 55

8) Percentiles or percentile numbers:

- The average web-based learning score of $10 \%$ of respondents is below 80.30

- The average web-based learning score of $25 \%$ of respondents is below 89.00

- The average web-based learning score $50 \%$ of respondents were under 96.00

- The average web-based learning score $75 \%$ of respondents were under 104.00

- The average web-based learning score $90 \%$ of respondents were under 112.70

9) Web-based learning score frequency distribution

Table 2. Web-based learning score frequency distribution

\begin{tabular}{lcc}
\hline $\begin{array}{l}\text { Interval } \\
\text { Classes }\end{array}$ & $\begin{array}{c}\text { Absolute } \\
\text { Frequency }\end{array}$ & $\begin{array}{c}\text { Relative } \\
\text { Frequency }(\%)\end{array}$ \\
\hline $65-72$ & 2 & 3.23 \\
$73-80$ & 3 & 4.84 \\
$81-88$ & 9 & 14.52 \\
$89-96$ & 23 & 37.10 \\
$97-104$ & 15 & 24.19 \\
$105-112$ & 7 & 11.29 \\
$113-120$ & 3 & 4.84 \\
Total & 62 & 100 \\
\hline
\end{tabular}

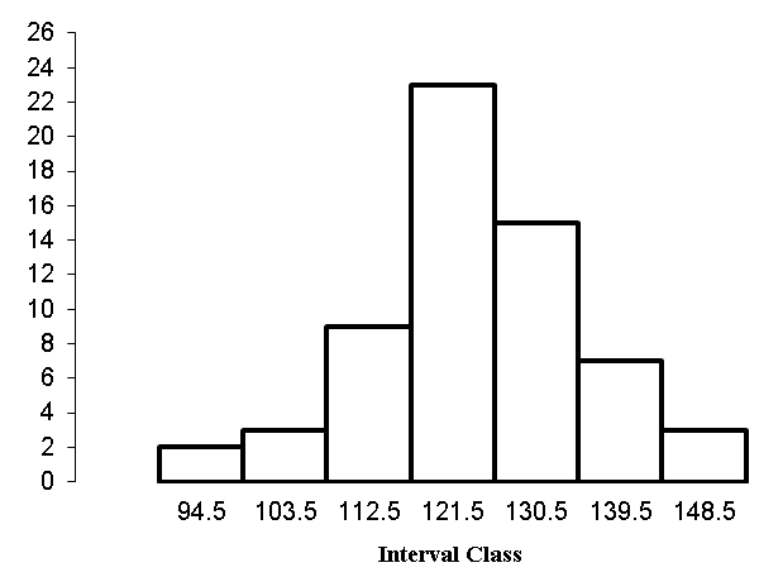

Figure 2. Histogram Web-based learning

Figure 2. indicates that the data grouping is based on calculations by using Sturges rule obtained the data centralizing values as follows; mode $=101.59$ mean $=96.03$ and median $=96.00$.

\section{Cultural literacy}

Based on the results of the descriptive analysis output with the program SPSS version 21.0 for cultural data literation obtained the following results:

1) $\mathrm{N}$ or the amount of valid data (valid for processing) is 62

2) The mean or average cultural literacy score is 96.92 with default error 1.11. At a confidence level of $95 \%$ with the default error of mean 1.11, It is estimated that a large average population literacy cultural score estimated from the sample is $96.92 \pm(2 \times 1.11)=\mathrm{A}$ score of 94.97 up to a score of 99.14 .

3) The Median or midpoint data if all data is sorted and divided by two equally large. The median number 96.50 showed that the 50\% educator performance score was 96.50 upwards and $50 \%$ was 96.50 down.

4) The standard deviation is 8.74. For that at a confidence level of $95 \%$ with a standard deviation of 8.74 then, the average dispersion of the sample is $96.92 \pm(2 \times 8.74)=$ A score of 79.44 up to a score of 114.4 .

5) The Skewness size is-0.363. For the assessment, the value is changed to the ratio number. The skewness ratio is the skewness value/default error skewness. Thus, the ratio skewness $=-0,363 / 0,304=-1.19$. As a guideline, if the skewness ratio is between- 2 to +2 , then the distribution of data is normal. Therefore-1.19 lies in the area between-2 and +2 Hence it can be concluded that the data culture of literacy is a normal distribution.

6) Data minimum is score 70.00 and maximum data is score 115

7) The range is maximum data - minimum data is score 45

8) Percentiles or percentile numbers:

- The average literate culture score of $10 \%$ of respondents is below 85.30

- The average literate culture score of $25 \%$ of respondents is under 92.00

- The average literacy culture score $50 \%$ of respondents were under 96.50

- The average literacy culture score $75 \%$ of respondents were under 103.00

- The average literate culture score $90 \%$ of respondents were under 108.70.

9) Frequency distribution of cultural literacy scores 
Table 3. Cultural literacy score frequency distribution

\begin{tabular}{lcc}
\hline $\begin{array}{l}\text { Interval } \\
\text { Classes }\end{array}$ & $\begin{array}{c}\text { Absolute } \\
\text { Frequency }\end{array}$ & $\begin{array}{c}\text { Relative } \\
\text { Frequency }(\%)\end{array}$ \\
\hline $70-76$ & 1 & 1.61 \\
$77-83$ & 3 & 4.84 \\
$84-90$ & 7 & 11.29 \\
$91-97$ & 24 & 38.71 \\
$98-104$ & 16 & 25.81 \\
$105-111$ & 8 & 12.90 \\
$112-118$ & 3 & 4.84 \\
Amount & 62 & 100 \\
\hline
\end{tabular}

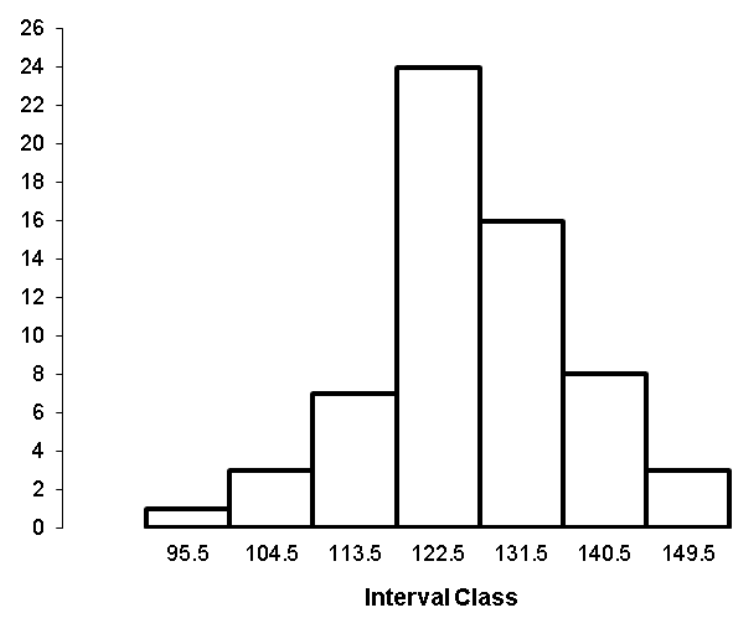

Figure 3. Histogram Cultural Literacy

Figure 3 indicates that the data grouping is based on calculations by using Sturges rule obtained the data centralizing values as follows; mean $=96.92$, median $=96.50$ and mode $=101.96$.

\section{Test Data normality}

To test data normality used two tests that are test Kolmogorov-Smirnov and Shapiro-Wilks. The calculation of both tests is done using SPSS program version 21.00.

\section{Criteria:}

If the significance value of $<\alpha$ is abnormal data distribution

if the value of significance is $>\alpha$ then it is normal data distribution

\section{Educator Performance}

Based on the put-out test of Normality for educator performance data acquired value significance for the Kolmogorov-Smirnov test amounted to 0.200 and a Shapiro-Wilk test of 0.780 . The value of that significance is greater than $\alpha=0.05$. Kolmogorov-Smirnov $0.200>0.05$ and a Shapiro-Wilk test $0.780>0.05$. Thus it can be concluded that the data is a normal distribution. This is also apparent in the Normal Q-Q Plot of performance educators whose data is scattered over a straight line that is formed from left to right. The same results are shown in the skewness ratio test on the descriptive analysis.

\section{Web-based Learning}

Based on the put-out test of Normality for Webbased learning data acquired significance value for Kolmogorov-Smirnov test amounted to 0.200 and a Shapiro-Wilk test of 0.611 . The value of that significance is greater than $\alpha=0.05$. Kolmogorov-Smirnov $0.200>0.05$ and a Shapiro-Wilk test $0.611>0.05$. Thus it can be concluded that the data is a normal distribution. This is also apparent in the Normal Q-Q Plot of web-based learning that the data is scattered over a straight line that is formed from left to right. The same results are shown in the skewness ratio test on the descriptive analysis.

\section{Cultural literacy}

Based on the put-out test of Normality for cultural literacy data obtained the significance value for the Kolmogorov-Smirnov test of 0.200 and a ShapiroWilk test of 0.563 . The value of that significance is greater than $\alpha=0.05$. Kolmogorov-Smirnov $0.200>$ 0.05 and a Shapiro-Wilk test $0.563>0.05$. Thus it can be concluded that the data is a normal distribution. This is also apparent in the Normal Q-Q Plot of a culture of literacy whose data is spread over a straight line that is formed from left to right. The same results are shown in the skewness ratio test on the descriptive analysis.

Based on the test results using SPSS Ver. 21, the data normality is obtained as in Table 4 .

Table 4. Tests of Normality

\begin{tabular}{ccccccc}
\hline & \multicolumn{3}{c}{ Kolmogorov-Smirnov ${ }^{\mathrm{a}}$} & \multicolumn{3}{c}{ Shapiro-Wilk } \\
\cline { 2 - 7 } & Statistic & df & Sig. & Statistic & df & Sig. \\
\hline Y & .066 & 62 & $.200^{*}$ & .987 & 62 & .780 \\
X1 & .068 & 62 & $.200^{*}$ & .984 & 62 & .611 \\
X2 & .072 & 62 & $.200^{*}$ & .983 & 62 & .563 \\
\hline
\end{tabular}

a. Lilliefors Significance Correction

*. This is a lower bound of the true significance.

Testing influences cultural literacy towards educator performance $\mathrm{Y}$ regression equation over $\mathrm{X} 2$

Based on the Coefficient Rebel on the column Unstandardized Coefficients acquired regression equation $50.107+0.571 \mathrm{X} 2$

$\mathrm{Y}=$ Educator Performance

$\mathrm{X}_{2}=$ Culture of Literation

A constant of 50.107 states that if there is no literate culture, the educator's performance is 50.107. 
The 0.571 regression coefficient states that any addition of 1 cultural literacy value will increase educator performance by 0.571 educators ' performance.

Table 5. Y regression equation over $\mathrm{X}_{2}$

\begin{tabular}{|c|c|c|c|c|}
\hline \multirow{3}{*}{ Model } & \multicolumn{4}{|c|}{ UnstandardizedStandardized } \\
\hline & Coef & cients & Coefficients & \\
\hline & B & $\begin{array}{l}\text { Std. } \\
\text { Error }\end{array}$ & Beta & Sig. \\
\hline (Co & 50 & 10.431 & & 4.804 .000 \\
\hline $\mathrm{X} 2$ & .571 & 107 & .566 & 5.324 .000 \\
\hline
\end{tabular}

a. Dependent Variable: Y

\section{Regression coefficient}

The statistical hypothesis to be tested:

Ho Py $2=0$ (no cultural influences on educator performance)

Ho Py $2 \neq 0$ (there is an influence of cultural literacy towards educator performance)

Criteria: If the value of significance of the $<\alpha$ conclusion is rejected Ho, otherwise if the value of significance $>\alpha$ the conclusion Ho received

Based on the results of SPSS program analysis, in the correlations table obtained the value $\mathrm{R}=0.57$ with significance 0.00 . Because the value of significance is less than $\alpha$ value $=0.05$, Ho is rejected. This means there is a cultural relationship between literacy to educator performance. From the table, model Summary obtained R Square 0.321 or $32.1 \%$, meaning as much as $32.1 \%$ regression model of the $\mathrm{Y}$ function (educator performance), can be explained by the cultural Literacy factor (X2).

\section{Coefficient Test Regression}

Testing the significance of cultural influences of Literation (X2) on educator Performance (Y)

Hypothesis

Ho: $\beta=0$ (no cultural influences of literation on educator performance)

$\mathrm{H} 1: \beta \neq 0$ (there is a cultural influence of literacy towards educator performance)

According to the ANOVA table, it reads the value $\mathrm{F}=28.346$ with a significance value of 0.00 . Because the value of significance is less than $\alpha$, i.e. 0.00 $<0.05$ then Ho is rejected. Thus there is an influence on the level of cultural literacy towards educator performance.

Table 6. ANOVA To test the significance and linearity of the performance educators over literacy culture

\begin{tabular}{lllll} 
ANOVA $^{\mathrm{b}}$ & & & & \\
\hline Model & $\begin{array}{l}\text { Sum of } \\
\text { Squares df }\end{array}$ & $\begin{array}{l}\text { Mean } \\
\text { Square }\end{array}$ & F & Sig. \\
\hline
\end{tabular}

\section{Residual $\quad 3215.83260 \quad 53.597$ \\ Total 4735.09761}

a. Predictors: (Constant), X2

b. Dependent Variable: Y

\section{Testing the significance of constants on linear} models(a)

Hypothesis cant)

Ho: $\mathrm{a}=0$ (Regression coefficient $\mathrm{A}$ is not signifi-

$$
\mathrm{H}_{1}: \quad a \neq 0 \text { (Regression coefficient a significant) }
$$

Based on the table Coefficients retrieved the value $\mathrm{t}=4.804$ with a significance value of 0.00 . Because the value of significance is less than $\alpha$, i.e. $0.00<$ 0.05 then Ho is rejected. Thus a regression coefficient is significant.

\section{Test the significance of the literate culture varia- ble coefficient (b) on the linear model}

Hypothesis

Ho: $\beta=0$ (Regression coefficient in the culture of literation is not significant)

$\mathrm{H}_{1}: \quad \beta \neq 0$ (Regression coefficient in significant literacy culture)

Based on the table Coefficients retrieved the value $\mathrm{t}=5.324$ with a significance value of 0.00 . Because the value of significance is less than $\alpha$, i.e. $0.00<$ 0.05 then Ho is rejected. Thus the regression coefficient in the literate culture is significant. Thus, the regression model $50.107+0.571 \mathrm{X} 1$, can be used to predict $\mathrm{Y}$ (educator performance level).

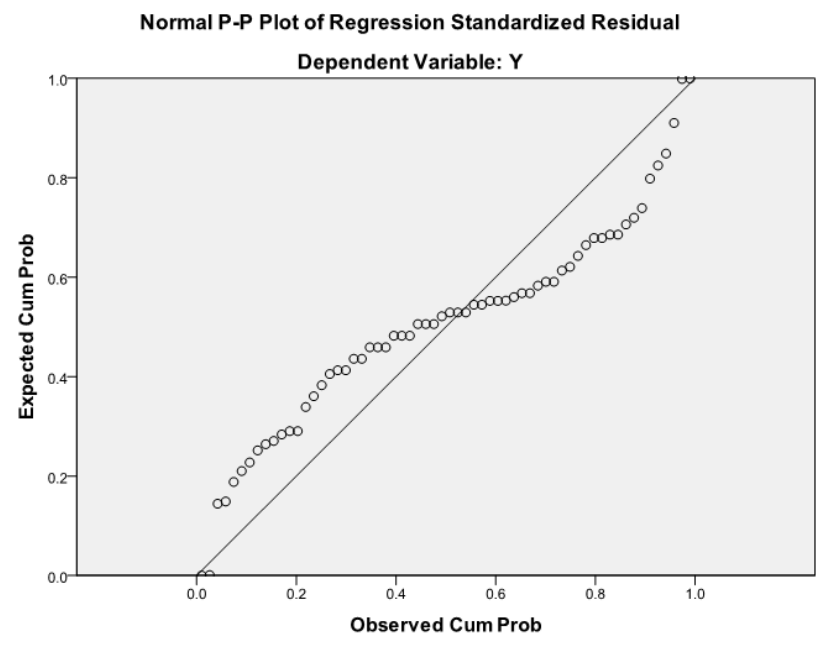

Figure 4. Linear Regression line graphs $\hat{\boldsymbol{Y}}=$ $50,107+0,571 \mathrm{X}_{2}$

Testing the influence of Web-based learning (X1) and Cultural Literacy (X2) on educator Performance (Y) 
To test the influence of Web-based learning (X1), the Literacy Culture (X2) on educator Performance (Y) is used multiple regression.

Multiple regression coefficients

The statistical hypothesis to be tested:

Ho; $R_{y .12}=0$ (No influence of web-based learning and cultural literacy towards educator performance)

$\mathrm{H}_{1} ; \mathrm{R}_{\mathrm{y} .12} \neq 0$ (There is an influence of web-based learning and cultural literacy towards educator performance)

Criteria: If the value of significance of the $<\alpha$ conclusion declines Ho, otherwise

If the value of significance $>\alpha$ the conclusion Ho received

Based on the results of SPSS program analysis, in the correlations table obtained the value $\mathrm{R}=0.764$ with significance 0.00 . Because the value of significance is less than $\alpha$ value $=0.05$, Ho is rejected. This means there is a link between web-based learning towards educator performance. From the table, model Summary obtained R Square 0.584 or $58.4 \%$, meaning as much as $58.4 \%$ regression model of the $\mathrm{Y}$ function (educator performance), can be explained by a factor of web-based learning (X1) and Cultural Literacy (X2), the rest of $41.6 \%$ is explained by factors not included in this study.

\section{Test a regression linearity}

According to the ANOVA table, it reads the value $\mathrm{F}=41.398$ with a significance value of 0.00 . Because the value of significance is less than $\alpha$, i.e. 0.00 $<0.05$ then Ho is rejected. Thus there are influences on the level of web-based learning and cultural literacy towards educator performance. Thus, the regression model

$$
\hat{Y}=34,550+0,412 \mathrm{X}_{1}+0,323 \mathrm{X}_{2} \text {, can be used }
$$
to predict $\mathrm{Y}$ (educator performance level).

Table 7. ANOVA to test the significance and linearity of educator performance on the implementation of Web-based learning and literacy culture

\begin{tabular}{|c|c|c|c|}
\hline \multicolumn{4}{|l|}{ ANOVA $^{b}$} \\
\hline Model & Sum & of Mean & $\mathrm{Sir}$ \\
\hline 1Regressiol & 2764.868 & 21382.434 & $41.398 .000^{\mathrm{a}}$ \\
\hline Residual & 1970.229 & 5933.394 & \\
\hline Total & 4735.097 & 61 & \\
\hline
\end{tabular}

a. Predictors: (Constant), X2, X1

b. Dependent Variable: Y

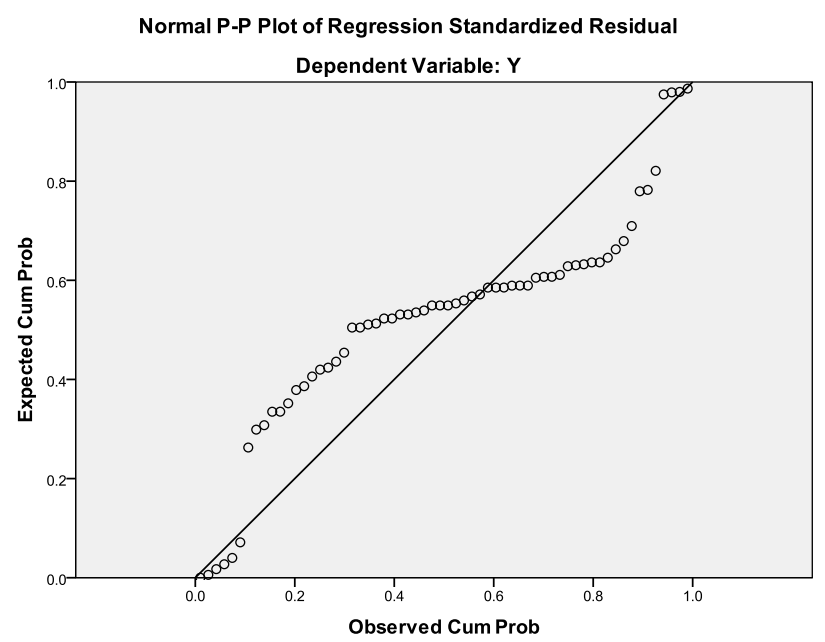

Figure 4. Linear Regression line graphs $\hat{Y}=34,550$ $+0,412 X_{1}+0,323 X_{2}$

\section{Discussion of Research}

Interpretation of research results refers to the test results of three research hypotheses, namely; (a) The influence of Web-based learning on the performance of Educators, (b) the influence of cultural literacy on educator performance, and (c) the influence of Webbased learning and cultural literacy to educator performance.

\section{Interpretation of Web-based learning influences on educator performance}

From a regression equation, it appears that every Web-based learning score is followed by rising educators ' performance scores or higher web-based learning, the higher the educator's performance. A review of the value of the coefficient of determination can be understood that $50 \%$ of educators ' performance variations can be explained by web-based learning. $50 \%$ is explained by other factors. This reinforces the argument that educator performance is determined by many factors among these factors as Web-based learning. Web-based learning of respondents on a real or $50 \%$ basis can improve educator performance.

The results of this study are supported by (Sakban, 2018) That web-based learning is a series of assisting educators in the form of professional services provided by supervisors (school supervisors, principals, and other coaches) to improve the quality of processes and results Learn to teach. The result of learning is to change the knowledge in his life, according to his opinion (Martinková, Hladká, \& Potužníková, 2020) the cognitive dimension of learning competence, i.e., general cognitive skills that facilitate the acquisition of new knowledge and the solving of non-routine tasks. Because the supervision or coaching of the educator is more emphasis on coaching the educator also "professional coaching educators" i.e. coaching 
is more geared towards improving efforts and improving the professional ability of educators. Webbased learning can be interpreted as coaching (Oliver \& Herrington, 2011). While the target of the construction can be for the principal, educator, administrative officers.

The research is also supported by (Fahriani, 2017), seen from the primary purpose of web-based learning is: (1) guiding and facilitating educators to develop their professional competencies, (2) Motivate educators to run their duties effectively, (3) Help educators manage their curriculum and KTSP-based Learning, (4) Helping educators build learners to make their potential grow to the fullest. The objectives that are intended to be achieved in the supervision are specifically formulated and degraded. If inferred, all contain an understanding of helping, accompanying, improving. All those goals are in the field of education and teaching.

Web-based learning activities are mandatory activities in the implementation of education. The Internet and the use of new information technologies lead to the advancement in learning and teaching methodologies (Genlott \& Grönlund, 2013). Web-based learning is a learning process that is done by utilizing the Internet network, so it is often also called elearning. The Internet is a network of thousands or even millions of computers, including the local network, connected through channels (satellites, phones, cables) and the range covers the entire world. The Internet has many facilities that can be used in various fields, including educational activities. These facilities include e-mail, Telnet, Internet Relay Chat, Newsgroup, Mailing List (Milis), File Transfer Protocol (FTP), or World Wide Web (WWW).

Web-based Teaching (WBI) as a hypermediabased teaching program that utilizes the World Wide Web (WEB) attributes and resources to create a conducive learning environment. The International Convention, stating that e-learning refers to the use of various electronic processes and applications for learning, including CBT, WBI, CD, and others. Although web-based learning has a relatively moderate relationship of $50 \%$ of educators ' performance, it is statistically significant that the relationship is so significantly so that it cannot be ignored.

\section{Interpretation of the influence of cultural litera- tion on educator performance}

From the regression equation gained appears that any increase in cultural literacy scores followed by rising scores of educators ' performance or the higher the literacy culture, the higher the educator's performance. Reviewed from the value of the coefficient of determination can be understood that $32.1 \%$ of educator performance variations can be explained by the literacy culture, while at $67.9 \%$ are explained by other factors. This can be the basis of the argument that educator performance is determined by many factors among these factors is a culture of literacy. The real culture of literacy or $32.1 \%$ can improve educator performance. Policies require literacy movements in learners to be appreciated. But if the culture of reading is done only at the time before the lesson begins in school, certainly the results will be obtained will not influence many (Tri Wibisono \& Pandu Paksi, 2018). Younger generations need more time than that to be able to start familiarizing yourself with a reading routine.

Further, (Muttaqiin, 2015) stated that to read the process can further hone the pattern of critical and analytical thinking, it is worth reading as the receptive activity is done in tandem with reflective activity and produce output like a critical book review. In this way, our younger generation will not only be active and critical readers, but it can also slowly turn into a writer whose construction will be more widespread. Massive policies and programs for launching a culture of literacy from local governments are also expected. Not only provide books in existing regional libraries, or a bustling village library popping up after the rolling of village funds but how to create a generation accustomed to reading.

First, the smallest in the vicinity of the house, for example, can be provided information corner by providing various literature that can be read by the child and other people also. If this is considered too extravagant, it refers to the policy of the child's proper city as contained in the regulation of the Minister of Women Empowerment and child protection number 11 and 12 years 2011 concerning the policy of district/city proper development of children and its indicators, child-friendly playroom or the play corner is one of the indicators that must exist if an area wants to be called worthy The existence of this play corner can be syllable with a reading corner for the child. So, in addition to educational games for children, the book must also be provided in it. It can be a valuable input for every village that currently has its source of funds from the allocation of village funding.

Secondly, once there is a library or information corner that is integrated with a child-friendly playroom is required a program that makes reading it an interesting activity to do and if required. The initiative to apply special time as study hours or the hour of reading is applied. For example, at $7 \mathrm{pm}$ it is enforced simultaneously as a child's time to read and or to study at home with the supervision of an adult or its parent. This regulation must be mutually agreed upon by all communities to be carried out every day. If children are wandering outside the house during 
these hours, the parents and their children are called by ward administrators to get a warning. If the rules are made, there must be sanctions and rewards for those who have executed.

Although the literacy culture has a relatively small relationship of $32.1 \%$ of the educator's performance, it is statistics that the relationship is significant so that it cannot be ignored. It is supported by opinions (Mahardhani, 2015) that high-performance educators will improve the quality and quality of education. Every educator must have high performance to produce various achievements that benefit him, the students, and the community. In carrying out his work will look at the way and motivation that an educator has, whether he or she works sincerely or not, responsibly or not. The way a person lives and performs his work is determined by the views, hopes, and habits of his working group. Therefore, one's performance can be influenced by its ability to manage its work (Lee, Sheldon, \& Turban, 2003).

The factors that can support and improve the culture of literacy in the effort to improve its performance, namely: the ability to understand and behave in Indonesian culture as the identity of the nation. Meanwhile, the literacy of citizenship is the ability to understand the rights and obligations of citizens. Thus, cultural literacy and citizenship are the ability of individuals and communities to behave in their social environment as part of a culture and nation. This literacy skill became an important thing to master in the 21 st century. Indonesia has a diverse range of nationalities, languages, customs, customs, beliefs, and social layers (Pratiwi \& Asyarotin, 2019).

Factors that affect educators ' performance in the learning process: (1) personal factors include skills, abilities, and confidence, (2) Leadership factors include quality in encouraging, encouragement, direction, and support. (3) System factors including working system, work facility or infrastructure provided by colleagues in one team (García-Morales, JiménezBarrionuevo, \& Gutiérrez-Gutiérrez, 2012). While the factors that can decrease educator performance (Finch, Hamilton, Baldwin, \& Zehner, 2013) among them; Gaps, ineffective awarding, absence of authority, unbalanced supervision, inflexible careers, personnel obsolesce, recruitment and unproductive selection efforts, the injustice of assignment and promotional opportunities.

\section{Interpretation of the influence of web-based learn- ing and cultural literacy towards educator per- formance}

From the regression equation gained appears that any increase in web-based learning scores and literacy culture, followed by rising educators ' performance scores or the higher web-based learning and literacy culture, the higher the performance Educators. By referring to the size of the regression coefficient values range from -1 to 1 , and by understanding that the positive regression coefficient has value; (a) $0.00-$ 0.20 did not regression, (b) $0.21-0.40$ weak regressions, (c) $0.41-0.60$ medium-regression, (d) $0.61-$ 0.80 strong regression, and (e) $0.81-1.00$ highregression, the regression of web-based learning against educator performance Ry $1=0.50$, regressions Moderate, while the cultural regression of literacy against the educator's performance Ry $2=0.321$ has a weak regression. The combination of web-based learning and literacy culture shows a coefficient of 0.584 medium-regression. This means that both factors, (a) Web-based learning, and (b) the Shared literacy culture can determine the performance of educators.

Jointly web-based learning and cultural literacy regressions to the educator's performance has a regression coefficient of Ry. $12=0.764$. Percentage of the performance of educators that can be explained jointly by web-based learning and cultural literacy of $76.4 \%$. This result is derived from a large coefficient of multiple regression determination ( $\mathrm{r} 2)$ of 0.584 . Thus $41.6 \%$ of educator performance variations are explained by other factors. The results of this research are supported by (Effendi, 2016) Explaining web-based learning is the process of learning to teach by utilizing the Internet network, so it is often called also with e-learning. The results research another aimed to explore students' online behaviors in the use of an online learning package and predict their outcomes with variables related to the package (Foung \& Chen, 2019). The Internet is a network of thousands or even millions of computers, including the local network, connected through channels (satellites, phones, cables) and the range covers the entire world. The Internet has many facilities that can be used in various fields, including educational activities. These facilities include e-mail, Telnet, Internet Relay Chat, Newsgroup, Mailing List (Millis), File Transfer Protocol (FTP), or World Wide Web (WWW). Webbased teaching as Hypermedia-based teaching programs that utilize attributes and resources World Wide Web (Web) to create a conducive learning environment. The International Convention, stating that elearning refers to the use of various electronic processes and applications for learning, including CBT, WBI, CD, and others.

Sociocultural approaches to digital literacy development were not fully elaborated in students' responses. For instance, one student described their digital literacy development thus: "I believe it was a combination of ...collaboration and learning from friends, and some teacher assistance (Genlott \& Grönlund, 2013). E-learning experience requires the 
discreetness and cunningness of an intelligent and fast thinker faculty member who can convert the principles and strategies in any position to make up events and their unique requirements (Mirzamohammadi, 2017). E-Learning is an instruction process that involves the use of electronic equipment in creating, assisting in the development, delivering, assessing and facilitating the learning process of learners as the center of the Interactive anytime and anywhere (Imam Shofwan, Shofwan, Desmawati, Raharjo, \& Widya Santosa, 2019). In addition to Web-based learning is interpreted as learning through the Internet, intranet, and Web pages only. Web-based learning can also be interpreted as web/Internet utilization for learning. Utilization can be a source of teaching materials and learning media.

\section{CONCLUSION}

There is a positive and significant influence on Web-based learning to the performance of informal educators in Gorontalo city, meaning the better webbased learning is the better the educator performance.

There is a positive and significant influence of cultural literacy towards the performance of nonformal educators in Gorontalo city, meaning the higher the literary culture scores the higher the educators ' performance, and the less the lower the literacy culture scores increasingly Low-level educator performance

There is a positive and significant influence on Web-based learning and the literary culture together with the performance of non-formal educators in Gorontalo city, this means that the higher the webbased learning and literacy culture the higher the educator's performance.

\section{REFERENCES}

Asf, J., \& Mustofa, S. (2013). Supervisi Pendidikan Terobosan Baru Dalam Peningkatan Kinerja Pengawas Sekolah dan Guru. Yogyakarta: Ar Ruzz Media.

Celik, S. (2011). Characteristics and competencies for teacher educators: Addressing the need for improved professional standards in Turkey. Australian Journal of Teacher Education, 36(4), 73-87.

Chiappe, A., \& Lee, L. L. (2017). Open teaching: A new way on e-learning? Electronic Journal of ELearning, 15(5), 369-383.

Deni Darmawan. (2012). Pendidikan Teknologi Informasi dan Komunikasi. Bandung: PTRemaja Rosdakarya.

Effendi, M. (2016). Integrasi Pembelajaran Active Learning dan Internet-Based Learning dalam
Meningkatkan Keaktifan dan Kreativitas Belajar. Nadwa, 7(2), 283.

Fahriani, Z. (2017). Kecerdasan Emosional Guru Terhadap Kultur. An-Nizom, 2(2), 417-431.

Finch, D. J., Hamilton, L. K., Baldwin, R., \& Zehner, M. (2013). An exploratory study of factors affecting undergraduate employability. Education and Training, 55(7), 681-704.

Foung, D., \& Chen, J. (2019). A Learning Analytics Approach to the Evaluation of an Online Learning Package in a Hong Kong University. Electronic Journal of E-Learning, 17(1), 11-24.

García-Morales, V. J., Jiménez-Barrionuevo, M. M., \& Gutiérrez-Gutiérrez, L. (2012). Transformational leadership influence on organizational performance through organizational learning and innovation. Journal of Business Research, 65(7), 1040-1050.

Genlott, A. A., \& Grönlund, Å. (2013). Improving literacy skills through learning reading by writing: The iWTR method presented and tested. Computers and Education, 67, 98-104.

Imam Shofwan, I., Shofwan, I., Desmawati, L., Raharjo, T., \& Widya Santosa, I. (2019). Homeschooling: Nonformal Education Learning Strategy 4.0, 382(Icet), 655-660.

Israfilov, N., Borisova, O., Kartashova, O., Davydova, N., Biserova, G., \& Gryaznukhin, A. (2020). Motivation and Employee Effectiveness in Online Learning Environments: Leadership Strategies of New Generation and Emotional Intellect. International Journal of Emerging Technologies in Learning (IJET), 15(09), 258.

Klassen, R. M., \& Kim, L. E. (2019). Selecting teachers and prospective teachers: A metaanalysis. Educational Research Review, 26(May 2018), 32-51.

Koswara, K., \& Rasto, R. (2016). Kompetensi Dan Kinerja Guru Berdasarkan Sertifikasi Profesi. Jurnal Pendidikan Manajemen Perkantoran, 1(1), 61.

Kusuma, A. H. P. (2017). Pengaruh kompetensi, budaya organisasi dan motivasi terhadap kinerja dosen perguruan tinggi swasta di kota makassar, 3(008), 88-100.

Lee, F. K., Sheldon, K. M., \& Turban, D. B. (2003). Personality and the goal-striving process: The influence of achievement goal patterns, goal level, and mental focus on performance and enjoyment. Journal of Applied Psychology, 88(2), 256-265.

Mahardhani, A. J. (2015). Kepemimpinan ideal kepala sekolah. Jurnal Dimensi Pendidikan Dan Pembelajaran, 3(2), 1-4.

Martinková, P., Hladká, A., \& Potužníková, E. (2020). Is academic tracking related to gains in learning competence? Using propensity score 
matching and differential item change functioning analysis for better understanding of tracking implications. Learning and Instruction, 66(November 2019), 101286.

Mirzamohammadi, M. H. (2017). The feasibility of E-Learning implementation in an Iranian university. Electronic Journal of E-Learning, 15(5), 423432.

Müller, N. M., \& Seufert, T. (2018). Effects of selfregulation prompts in hypermedia learning on learning performance and self-efficacy. Learning and Instruction, 58(May), 1-11.

Muttaqiin, A. (2015). Hubungan Antara Kemampuan Membaca Kritis Dalam Pembelajaran Penemuan Dan Kemampuan Berpikir Kritis Siswa. Edusentris, 2(2), 116.

Oliver, R., \& Herrington, J. (2011). Using Situated Learning as a Design Strategy for Web-Based Learning. Instructional and Cognitive Impacts of Web-Based Education, 178-191. Patrick, K. (2011). Teacher Education in Kenya: Emerging Issues. International Journal of Curriculum and Instruction, 1(1), 43-52. Retrieved from http://www.muk.ac.ke/ijci/

Pratiwi, A., \& Asyarotin, E. N. K. (2019). Implementasi literasi budaya dan kewargaan sebagai solusi disinformasi pada generasi millennial di Indonesia. Jurnal Kajian Informasi \& Perpustakaan, 7(1), 65-80.

Rafiola, R. H., Setyosari, P., Radjah, C. L., \& Ramli, M. (2020). The Effect of Learning Motivation, Self-Efficacy, and Blended Learning on Students' Achievement in The Industrial Revolution 4.0. International Journal of Emerging Technologies in Learning (IJET), 15(08), 71. Sakban. (2018). Manajemen Sumber Daya Manusia (Studi Terhadap Pengelolaan Tenaga Guru Di Madrasah Aliyah Al- Mathiriyah Muara Rupit Kabupaten Musi Rawas Utara). Institus Agama Islam Negeri Curup.
Saputra, M., \& Siddiq, I. H. Al. (2020). Social Media and Digital Citizenship: The Urgency of Digital Literacy in The Middle of A Disrupted Society Era. International Journal of Emerging Technologies in Learning (IJET), 15(07), 156.

Sukarno, \& Sumarwati. (2020). Participants' perceptions of the effectiveness of online continuing professional development for principals in central Java, Indonesia. International Journal of Instruction, 13(2), 477-492.

Susilo, M. E. (2017). Prosiding seminar nasional tahun ke-3 | call for paper, dan pameran hasil penelitian \& pengabdian masyarakat kemenristekdikti ri, 88-95.

Thomas, A. (2013). Kecerdasan Multipel di dalam Kelas. Jakarta.

Tri W. Y., \& Pandu P. H. (2018). Implementasi Program Gerakan Literasi Sekolah Di Sdn Sumurwelut Iii/440 Surabaya. Jurnal Penelitian Pendidikan Guru Sekolah Dasar, 6(13), 2394-2404.

Vipraprastha, T., \& Sari, M. M. R. (2016). Pengaruh Faktor-Faktor Kinerja Individual Karyawan Terhadap Efektivitas Penggunaan Sistem Informasi Akuntansi. E-Jurnal Akuntansi Universitas Udayana, 15(3), 1826-1855.

Voogt, J., Knezek, G., Cox, M., Knezek, D., \& Ten Brummelhuis, A. (2013). Under which conditions does ICT have a positive effect on teaching and learning? A Call to Action. Journal of Computer Assisted Learning, 29(1), 4-14.

Yani, A. dan A. I. (2016). MANAJEMEN SUMBER DAYA MANUSIA (Studi Terhadap Pengelolaan Tenaga Guru Di Madrasah Aliyah AlMathiriyah Muara Rupit Kabupaten Musi Rawas Utara). JPBM (Jurnal Pendidikan Bisnis Dan Manajemen), 2(1), 58-74.

Zhu, W., Chew, I. K. H., \& Spangler, W. D. (2005). CEO transformational leadership and organizational outcomes: The mediating role of humancapital-enhancing human resource management. Leadership Quarterly, 16(1), 39-52. 